\title{
Implementation of Nepal's Education Policy in ICT: Examining Current Practice through an Ecological Model
}

\author{
Karna Rana
}

\begin{abstract}
Educational policy implementation can be conceptualised in terms of an ecological model that explores roles and relationships within a complex evolving environment. This article draws on an ecological model to examine Nepal's implementation of its policy for information and communication technology (ICT) in education. The policy is developed by government and mandated to schools, but the government does not commit funding to resource infrastructures or to train teachers in ICT use. Instead, nongovernment organisations and particularly Open Learning Exchange, have stepped into the niche and provided resources and training in rural schools. Thus, two separate, though interconnecting, systems have evolved. This article examines their actions and interactions as components within an ecology. It reports findings of how a largely symbiotic relationship has evolved that is to some extent successful in meeting immediate needs. It reports and examines changes that are already developing in the ecology and considers changes that may occur in the future and discusses how these may impact on balances within the ecology and so on the future of ICT implementation in Nepal.
\end{abstract}

Keywords: ICT, education, policy, ecology, NGOs

\section{Introduction}

Nepal has a firm policy for the introduction of information and communication technology (ICT) in education, and emphasises the need for such technology in order for its schooling to align with global practices. However, research (Rana, 2018) has identified problems in the introduction of ICT in rural primary education in Nepal and has suggested that government strategies currently used to overcome them are inadequate and potentially unsustainable. In this article, the problems and means taken to address them are discussed in terms of an ecological model of practice (Weaver-Hightower, 2008). 
Firstly, we briefly outline the history of ICT in education in Nepal and suggest why an ecological framework is useful for understanding the ways policy is translated into practice. Then we review relevant literature and explain the methodological process of a research project that investigated the introduction of ICT in rural primary education in Nepal. Next, we report the initial findings of the research. Then we consider implications of the findings in terms of an ecological model. Finally, we examine the relative current success and future sustainability of the implementation of ICT in education in terms of the ecological model.

\section{Background}

Numerous attempts have been undertaken to transform learning and the schooling system in Nepal during the 1990 s and the first decade of the $21^{\text {st }}$ century (Carney \& Bista, 2009; Carney \& Rappleye, 2011). In 1992, the Government of Nepal agreed to adopt the Education for All policy, signed by many other countries internationally, at the World Summit Thailand 1990 (ibid). This was followed by a declaration by the government that education should be active in modernising society and in the development of its individual citizens. In 2005, the National Curriculum Framework for School Education introduced ICT to be used as "a proven tool for educational transformation” (MoES, 2005), without defining these terms or providing means to evaluate their achievement. In 2007, the National Curriculum Framework for School Education in Nepal stated that ICT was to be used for communicating and transmitting information and as a tool for teaching other subjects, as well as developing the study of ICT as a distinct subject (MoES, 2007). However, later government documents (MoE, 2009, 2016) acknowledged that funding had not been made available for the integration of ICT. Nevertheless, successive government plans and policy statements have reiterated the purpose of integrating ICT as a tool for instructional purposes.

Previous research (Rana, 2018; Rana, Greenwood, Fox-Turnbull \& Wise, 2018) as well as the findings briefly summarised in this article have emphasised the gap that exists 
between government policy and the implementation of that policy into practice and have critically examined the effect of relegating the provision of ICT infrastructures and training to NGOs. Here that gap is reconsidered in terms of (Weaver-Hightower, 2008) ecological model of policy implementation.

\section{Review of Literature}

The literature relevant to this report can be considered in terms of four interrelated strands: that which reports the status of ICT in schooling in Nepal, that which examines the role NGOs play in development, that which discusses the role of Nepal's educational policy and its relationship to practice, and that which applies ecological conceptualisations to policy.

There is a small body of writings related to the status and practice of ICT in education in Nepal. Several researchers (Dawadi \& Shakya, 2016; Pangeni, 2016; Rennie \& Mason, 2007; Shields, 2011) reported the expansion of internet infrastructures throughout Nepal and suggested that these should increase the possibility of e-learning and enable school teachers to access the latest online information and so facilitate rural school students' education. However, Thapa and Saebo (2011) reported that lack of high-quality internet, electricity and supporting infrastructure are major challenges in Nepal's rural schools. Dawadi and Shakya (2016) reported the lack of skilled workforce, unreliable and costly internet facility, low level of ICT literacy in rural communities, high hills and mountains, lack of hydropower in the countryside and low power solar energy and lack of security for ICT infrastructures. Rana (2018) reported a range of problems in the introduction of ICT in rural primary education in Nepal and suggested that the strategies currently used to overcome them are inadequate and potentially unsustainable.

Internet World Stats (2017) reported that about 21.9\% of the total population in Nepal were active Facebook users in early 2017, and it was calculated that the number of internet users crossed 58.72\% of the total population in the mid-2017 (News24Nepal, 2017). 
However, there is little evidence of school teachers in rural areas in Nepal participating in online communities and share their problems and ideas. Thapa (2011) has argued that although the Nepal Wireless Network Project, which uses ICT in various sectors such as health, education and micro-level business in rural communities in a mountainous district in Nepal, has potentially improved many aspects of rural communities, it is very costly for the people who cannot afford expensive digital technologies. Sharma (2019) notes that per capita income in Nepal is about US\$730 and so the poor economic status of many individuals is a barrier to afford expensive digital technology.

Bhatta (2008) identified that teachers in rural primary schools needed to develop computer literacy. Smith (2009) found that, although Schools of Education are responsible for improving the quality of initial teacher training, teacher education programme in Nepal do not cover ICT education. Dixit (2009), however, reported that radio, one particular ICT tool, was integrated into teacher training in 1980 and has continued in training programmes in Nepal. Bhatta (2008) argued that the generic teacher training module should be redesigned on the basis of ICT implementation to enable teachers to stay up to date with improving practices in their teaching. He noted the challenge lies in how teachers can integrate digital content into their teaching. However, the School Sector Development Plan, 2016 -23 states that funding for equipping primary schools with ICT infrastructure is not available (MoE, 2016).

Several studies (Ivins, 2011; Thapa \& Saebo, 2011) have emphaised the significance of local language in the multilingual context of Nepal in developing access and digital content. Similarly, studies in Bangladesh (Ashraf, Hanisch \& Swatman, 2009; Islam, 2010; Khan, Hossain, Hasan \& Clement, 2012) found language to be one of the major barriers to the effective classrom use of ICT as English is dominant in computer software. 
The World Bank (2015) has noted that developing countries like Nepal are probably not able to invest extensively in ICT in education. It suggests the need for developing countries to have public-private partnerships for adopting technology in education. Since a number of NGOs have created partnerships with schools, writings about the impact of NGOs constitute the second strand of this review. The 1991 change in consitution provided an open door policy to establish NGOs and get direct access to international funds to invest in various social welfare activities (Bhandari, 2014). The Asian Development Bank (2005) reported that the number of NGOs in Nepal crossed 60,000 in the year 2005, and Bhandari and Onta (2017) estimated that the number of NGOs might be over one hundred thousand. NGO reports highlight the ways they support schools, students and teachers with digital resources, distance learning materials and technical support. For example, Open Learning Exchange, an NGO, reported its provision of an open access base e-library and digital resources for primary level courses (MyRepublica, 2017)the official website of Scientology (2017) reported that Applied Scholastics Training Centre in Nepal has built a network of over 1600 technology teachers.

There are numerous critiques of the impact of NGOs on developing countries. Beyer (2007) discussed the ways international organisations leverage the state policy through local NGOs. Lister (2003) argued that, although the general perception of NGOs is that they are organisations intended to deliver public service, advocacy and community development, the actual aims and beneficiaries of such organisations are not well theorised. Terje (1998) stated that development NGOs work with the hidden interests of international NGOs or donor agencies to intervene in under-developed and developing countries and that donor agencies do not disclose their vested interest. Wallenius (2017) found that the management of foreign support in Nepal promoted de facto privatisation in which international donor agencies worked to launch their programmes directly with Nepal’s NGOs. Rappleye (2011) argued 
that NGOs in Nepal act as catalysts to influence educational, economic and social policies, and overall development of the country. He showed that they do not manoeuvre independently, but operate as an institutionalisation of donor agencies' agendas and interests. Regmi (2017) argued that global rather than local interests prompted the reproduction of World Bank Policy to decentralise school management system in 2002. Banks, Hulme and Edwards (2015) argued that NGOs working with the interest of donor resources remain illequipped to intervene and unable to operate long-term transformative goals. However, they suggested that NGOs can play a significant role in bridging the government, markets and citizens. Ismail (2017) argued that foreign-funded NGOs are unlikely to counter neoliberal development. Tanaka (2011) argued that the majority of NGOs in the country belong to a group of elites and very rarely include members from excluded, marginalised and underprivileged communities. However, Gurung, Gurung, Karki and Bista’s (2011) study in the rural mountainous region of Nepal found that the NGOs' involvement, although limited in time, do make a contribution in various aspects of people's lives in economics, education and agriculture.

The third strand concerns writings about ICT policy. The National Curriculum Framework for School Education, 2005 mandated that "ICT as a proven tool for educational transformation” should be used in instructional activities in schools (MoES, 2005, p. 11). Shields (2011) argued that, although the integration of ICT is constituted to meet the national education goal of public service and quality education, the terms proven and transformation in the curriculum are vague and offer no means of evaluating change. The School Sector Development Plan, 2016 -23 stated that funding for equipping primary schools with ICT infrastructure is not available (MoE, 2016) and the ICT Policy, 2015 explicitly stated the government's intention to create public-private partnerships to provide ICT infrastructure in government schools (MoIC, 2015). Rana (2018, p. 20) highlighted the gap between the 
“aspirations and rhetoric of policy and the practicalities of funding and resources”. He detailed both the aspiration in policy to create an education system that aligns with global trends and the absence of any government provision for initial teacher training or professional development in ICT and the lack of any resourcing of infrastructures (networks, equipment, digital content or technical support), particularly in rural areas. Rana et al. (2018) documented how teachers in a number of rural schools utilised non-networked digital devices, provided by an NGO, in their teaching and noted that the most visible change in classroom practice was that in the place of a teacher dominated environment students tended to work more independently on their devices.

The complexities of implementation of government policies into specific programmes have been analysed in a range of studies. For example, Sabatier and Mazmanian (1980) noted the neglect of attention to policy implementation in policy documents, developed a framework that highlights the importance of "the strength of the statutes, particularly the degree of hierarchical integration, the commitment of agency officials, the presence of a 'fixer', and the resources of various contingency groups" (p.17), and argued that "it is changing socio-economic conditions and the ability of supportive constituency groups to effectively intervene in the process that are probably the most important” (p.17). Sabatier and Mazmanian (1980) emphasised that the implementation aspect, although it probably neglected in the development of the policy, needs to be clearly specified in order to achieve the policy goals. Rosenbaum (1980) stressed that effective implementation of policy depends on unambiguous and specific standards and criteria which should clearly explain what behavioural changes are required of bureaucracy and of the public. Ball (1998) suggested that in the post-modern era of global economy, the formation of policy and implementation process need to be considered in wider terms. He stated that the globalisation of economy, skills, education and resources has created an environment where all nations, even very 
powerful ones, have to be integrated to survive. He emphasised that policy development is “a process of bricolage, a matter of borrowing and copying bits and pieces of ideas from elsewhere, drawing upon and amending locally tried and tested approaches, cannibalising theories, research, trends and fashions” (p.126). Baker and Eckerberg (2013) suggested that policy, as a proposal of government to address public issues, needs to be understood as instrumental and it requires the management and mobilisation of resources in a specific environment. Weaver-Hightower (2008) stated that the analysis of policy implementation has radically moved away from traditional and functionalist interpretation of how a certain group of people create and implement policy.

The fourth strand involves the application of ecological concepts to policy implementation. Ecological systems have been approached and defined in various ways. For example, Bronfenbrenner (1979) focused on five environmental systems with which an individual interacts; Firestone (1989) proposed a model of overlapping games; WeaverHightower (2008) found the metaphor of games too limiting and argued for complex systems that included all the actors in the environment; and Yawson (2009) discussed innovation policy-making in terms of navigating a web of interlocking systems and pathways that have potential to sustain evidence-based policymaking.

In his exploration of educational policy as an ecology of games, Firestone (1989) described the agencies and even individuals involved as players who, while they may become winners or losers, each feed and are fed by others. Players are involved in separate games that co-exist in the same habitat and, like organisms in a natural environment, sometimes compete with and sometimes support each other in various ways. Zhao and Frank (2003) argued that in an ecological metaphor, when new organisms, such as computer technology which is an invading species, are introduced in the existing system which consists of native species, the competition and support between the organisms co-evolve a new ecology. Weaver-Hightower 
(2008, p.155) critiqued and expanded Firestone’s model and argued that "in many ways the game metaphor simply does not fit the ways that policy and policy formation actually operate" and that "unlike players in a game, actors in a policy process may have multiple roles, with the result that they can play on several competing teams simultaneously”. Firestone (1989) discussed competition and symbiosis as the two most obvious kinds of relationship that might be drawn from ecology to describe features of policy implementation. Weaver-Hightower (2008) discussed relationships in terms of competition, cooperation, predation and symbiosis. Further discussion of this theorisation is presented in the discussion section of this article.

\section{Methodology}

The research design of the project was one of qualitative case study, involving semistructured interviews with sixteen teachers from five rural schools in various remote regions, classroom observation of twelve teachers from three schools and a study of documents detailing national education policies of Nepal, school reform plans and education acts. After the field work, these documents were read against observational and interview data in order to capture the complexities of practice within the rural context.

The choice of approach was partially dictated by the context of rural Nepal: the landscape is mountainous and forested with new interconnecting roads and unreliable Wi-Fi connections; the 2015 earthquake in some districts had destroyed over $90 \%$ of the schools; while Nepali is the formal language of education, each region has its own language that is used in all social communications and to an extent even in schooling; educational research is not well established and what occurs is usually conducted by international organisations who pay for participation (Rana et al., 2018). Moreover, central educational agencies were found to hold little information about the actual conditions in individual rural schools (ibid). These factors suggested that survey was impractical and likely, moreover, to be unreliable. They 
also indicated a need for personal approach and sustained presence in a school community. The early stages of the project found lack of government or district records of which schools had obtained and were utilising digital devices. NGOs were able to report the schools they had supplied. Overall, however, information about rural schools’ practices had to be obtained throughout personal contact and referral.

The five rural schools were selected on the basis of reports by various NGOs about their digital usage and their willingness to participate in the research. In addition, it was intended to investigate schools that were impacted by the 2015 earthquake and those outside the region where the most destructive damage occurred. Each of these schools was seen as an individual case study within the multiple case of rural Nepali schools. As Stake (2006) notes, whether individual cases in the collection will manifest common characteristics may not be known in advance, but they are chosen in the belief that understanding them will lead to better understanding of the collective case. The schools and the teacher participants are summarised in the following table:

Table 1. Schools and teachers in the study

\begin{tabular}{|l|l|l|l|l|}
\hline \multicolumn{1}{|c|}{$\begin{array}{c}\text { School } \\
\text { pseudonyms) }\end{array}$} & \multicolumn{1}{|c|}{ Location } & \multicolumn{1}{c|}{$\begin{array}{c}\text { Community } \\
\text { context }\end{array}$} & Digital usage & $\begin{array}{l}\text { Teacher } \\
\text { Participants } \\
\text { (pseudonyms) }\end{array}$ \\
\hline Annapurna & $\begin{array}{l}\text { Mid-western } \\
\text { lowland region } \\
\text { Accessible by } \\
\text { walking on a rough } \\
\text { road }\end{array}$ & $\begin{array}{l}\text { In isolated village } \\
\text { surrounded by } \\
\text { dense forest and } \\
\text { wildlife national } \\
\text { park }\end{array}$ & $\begin{array}{l}\text { Reported to } \\
\text { be actively } \\
\text { using digital } \\
\text { devices }\end{array}$ & $\begin{array}{l}\text { Anuj } \\
\text { Ananda } \\
\text { Anita } \\
\text { Asha }\end{array}$ \\
\hline Buddha & $\begin{array}{l}\text { far-western } \\
\text { mountains } \\
\text { 36-hour bus journey }\end{array}$ & $\begin{array}{l}\text { Distinct ethnic } \\
\text { culture and } \\
\text { different language }\end{array}$ & $\begin{array}{l}\text { Reported to } \\
\text { be actively } \\
\text { using digital } \\
\text { devices }\end{array}$ & $\begin{array}{l}\text { Binod } \\
\text { Bijen } \\
\text { Bhupal } \\
\text { Bikash }\end{array}$ \\
\hline Chadani & $\begin{array}{l}\text { Rural but relatively } \\
\text { near capital city } \\
\text { In earthquake } \\
\text { disaster zone and } \\
\text { partly affected }\end{array}$ & $\begin{array}{l}\text { Bilingual } \\
\text { community, with } \\
\text { marginalised ethnic } \\
\text { community and }\end{array}$ & $\begin{array}{l}\text { Reported to } \\
\text { be actively } \\
\text { using digital } \\
\text { devices }\end{array}$ & $\begin{array}{l}\text { Chandra } \\
\text { Chiran } \\
\text { Chitra } \\
\text { Chetan }\end{array}$ \\
\hline
\end{tabular}




\begin{tabular}{|l|l|l|l|l|}
\hline & & $\begin{array}{l}\text { significant adult } \\
\text { illiteracy }\end{array}$ & \\
\hline Dhaulagiri & $\begin{array}{l}\text { In the hills of central } \\
\text { development region, } \\
\text { zone most impacted } \\
\text { by 2015 earthquakes }\end{array}$ & $\begin{array}{l}\text { The school lost all } \\
\text { its buildings and in } \\
\text { a village with } \\
\text { damaged houses }\end{array}$ & $\begin{array}{l}\text { Lost its } \\
\text { computer lab } \\
\text { in 2015 } \\
\text { earthquakes }\end{array}$ & $\begin{array}{l}\text { Deepa } \\
\text { Dinesh }\end{array}$ \\
\hline Ekata & $\begin{array}{l}\text { Two hours by bus } \\
\text { from capital city }\end{array}$ & $\begin{array}{l}\text { Located near the } \\
\text { capital city; easy } \\
\text { access to city } \\
\text { facilities. }\end{array}$ & $\begin{array}{l}\text { Had One } \\
\text { Laptop Per } \\
\text { Child project } \\
\text { running for } \\
\text { five years }\end{array}$ & $\begin{array}{l}\text { Ekendra } \\
\text { Elisha }\end{array}$ \\
& & &
\end{tabular}

Dhaulagiri School lost its computer lab in the April 2015 earthquake, so was not possible to observe their technology practice. Ekata School was later found to have kept their technology devices in a lab without using them for over two years. Of necessity the study’s focus in these schools was on recall of their previous experiences, their digital devices and the training they had received. Their accounts of discontinuation were in themselves noteworthy.

The teachers were generalist teachers teaching various subjects at primary level. Their teaching careers varied between three to twenty-nine years of service. In each school the headteacher acted as a mediator to organise an informal meeting with his teachers where the project was explained, and teachers were asked for their voluntary participation.

Audio recording of the interviews and informal conversations were transcribed, translated and coded using NVivo. In addition, the data from participants was approached as narrative of individual experiences and contextualised understandings. This aligns with the process of interpretative phenomenological analysis (IPA). Smith, Larkin and Flowers (2009) explain that IPA emphasises the subjective meanings that participants give their experiences: it is an analysis that is committed to understanding data from the perspective of participants at the same time as it calls on the researcher to interpret, that is to make sense, of what the participant is saying. The combination leads to a descriptive and interpretative presentation of 
findings clustered around key emergent themes: the training participants had received, the infrastructures that had been developed, the barriers they experienced, the specific use they made of digital devices in their teaching, the changes to their teaching approach and the changes in their relationship with students.

A further level of analysis, which is the focus of this article, was drawn from the policy ecology model of Weaver-Hightower (2008). This has afforded consideration of the relationship between what was found in field work at schools and what was found in government policy statements in terms of agencies, relationships and processes that are dynamic, evolving and orientated towards survival. In particular the findings are considered in terms of four key elements proposed by Weaver-Hightower: actors, relationships, enviroments and structures, and processes. Table 1 summarises the application of the key elements in Weaver-Hightower's model to analysis of the data from this study. The implications of applying this model are further discussed later in this article.

Table. 2: Application of key elements of Weaver-Hightower policy ecology to current data

\begin{tabular}{|c|c|c|}
\hline \multicolumn{2}{|l|}{ Elements } & Application to current research data \\
\hline \multicolumn{2}{|l|}{ Actors } & $\begin{array}{l}\text { Policy makers and government education agencies, } \\
\text { Schools and teachers, } \\
\text { NGOs }\end{array}$ \\
\hline \multirow[t]{4}{*}{ Relationships } & Cooperation & $\begin{array}{l}\text { NGO and government education agencies provide } \\
\text { different kinds of training to schools to integrate digital } \\
\text { technology in teaching and learning }\end{array}$ \\
\hline & Symbiosis & $\begin{array}{l}\text { Government education agencies provide generalist } \\
\text { initial teacher training and in-service courses } \\
\text { NGO provides training in ICT and basic equipment }\end{array}$ \\
\hline & Competitive & Not evident \\
\hline & Predatory & Not evident \\
\hline \multirow{3}{*}{$\begin{array}{l}\text { Environments } \\
\text { and } \\
\text { structures }\end{array}$} & Boundaries & NGO supports only government primary schools. \\
\hline & $\begin{array}{l}\text { Extant } \\
\text { conditions }\end{array}$ & $\begin{array}{l}\text { Developing country, urban-rural divide, poverty } \\
\text { geographical locations vulnerability to earthquakes, the } \\
\text { national policy and curriculum }\end{array}$ \\
\hline & Pressure & $\begin{array}{l}\text { Lack of government investment in ICT } \\
\text { Rural poverty }\end{array}$ \\
\hline
\end{tabular}




\begin{tabular}{|c|c|c|}
\hline & & Global movement towards digitalisation \\
\hline & Niche and roles & $\begin{array}{l}\text { Initial teacher training courses do not cover ICT } \\
\text { training } \\
\text { NGO takes initiative in providing ICT training and } \\
\text { basic infrastructure }\end{array}$ \\
\hline & Inputs & $\begin{array}{l}\text { Foreign aid to provide ICT resources and training } \\
\text { No government input in this area }\end{array}$ \\
\hline & $\begin{array}{l}\text { Niches and } \\
\text { roles }\end{array}$ & $\begin{array}{l}\text { Initial teacher training courses do not cover ICT } \\
\text { training. }\end{array}$ \\
\hline & $\begin{array}{l}\text { Adaptive } \\
\text { decentralisation }\end{array}$ & $\begin{array}{l}\text { Lack of centralised government control over the } \\
\text { implementation of ICT in education allows NGO to } \\
\text { take initiative }\end{array}$ \\
\hline & Agency & $\begin{array}{l}\text { NGO supports over } 43 \text { schools in a mountainous } \\
\text { district with ICT infrastructure, teacher training and } \\
\text { other essential resources }\end{array}$ \\
\hline \multirow[t]{7}{*}{ Processes } & Emergence & $\begin{array}{l}\text { Collaboration between NGOs and schools created } \\
\text { emergence of use of ICT in some rural primary schools }\end{array}$ \\
\hline & Entropy & $\begin{array}{l}\text { Devices breakdown but NGO does not provide new } \\
\text { replacements } \\
\text { Discontinued use by two schools } \\
\text { Uncertain future }\end{array}$ \\
\hline & Adaptation & $\begin{array}{l}\text { Gradually shifting the classroom teaching and learning } \\
\text { environment }\end{array}$ \\
\hline & Conversion & $\begin{array}{l}\text { No evidence of complete conversion } \\
\text { Teachers shuttle between textbook and digital devices } \\
\text { Examples of discontinued practice }\end{array}$ \\
\hline & Succession & No evidence of succession planning \\
\hline & Conservation & $\begin{array}{l}\text { Rural school teachers try to conserve provided } \\
\text { resources because they do not get replaced. } \\
\text { No evidence of plans to provide continuous resourcing }\end{array}$ \\
\hline & Anticipation & $\begin{array}{l}\text { No evidence of government planning to fill gap if } \\
\text { NGOs withdraw }\end{array}$ \\
\hline
\end{tabular}

A study of five schools does not offer a comprehensive and generalisable depiction of the practices of all rural primary schools in Nepal. However, by identifying relationships, possibilities and limitations that were evident in those schools, it allows exploration of how NGOs work with schools to make possible the implementation of policy and invited further research in this area. 


\section{Findings}

Although the primary focus of this article is to discuss the relationships and processes involved in the implementation in rural schools of the government's policy to integrate ICT in education, a brief overview of the overall findings of the project is offered as it highlights what has been done in implementing ICT in the schools studies and who it was done by.

\section{Two systems operating}

Analysis of policy and planning documents, together with accounts from teacher participants revealed that there are two systems operating in the implementation of ICT in education in Nepal. The first system evolves around government bodies which variously formulate and interpret policy (including the Ministry of Education, the Department of Education, the Curriculum Development Center, Center for Education and Human Resource Development, District Education Offices and Resource Center) and schools and their teachers who variously enact policy in their classrooms. The second system involves development non-government organisations (NGOs), who, in the absence of government investment, invest in providing ICT resources and training and the schools and teachers they supply. To an extent both systems operate separately: government articulates educational vision, creates policy, establishes administrative structures and funds some of the expenses of schools and some of the teachers' salaries; NGOs develop their own programmes based loosely on government policy and directly provide ICT devices and infrastructure and some training to selected schools, but they are not accountable to government. They are often accountable to other external international bodies. It can be said that NGOs have stepped into a niche created by the absence of government provisions for funding ICT and training teachers in its educational uses. In these terms the findings of the current research provide an alternative view, from the critiques cited in the literature review, to the contribution made by NGOs in development. 


\section{Training received}

The government made provision for generalist initial training for some teachers and provided, through district Education Offices, generalist continuing professional development courses. It was found that all the participants had received a course (of varying length) in ICT training from the NGO which supported their schools with ICT infrastructure, and that none of them had been introduced to technology in their pre-service training. For instance:

When we brought a computer to our school, I bought a smart mobile. My brother was far better in technology. I learned how to use a computer from him. There nothing about it in my college course. (Deepa)

Half of the participants did not have any computer skills before they received this training, and most of these had been initially reluctant to use the digital devices. Those who already had some familiarity with computers had acknowledged the real need to introduce digital devices into their schools. For example, participants recalled:

We said, 'This is new for us. Can we use them? It may be very difficult for us. We don't know what there is.' Then they convinced us, 'We'll make you perfect in seven days and send you back to your school knowing how to use them.' (Chandra)

We got general information from the people. Simply, they said it is just a computer. We already had solar energy. They were happy to provide this technology and we were happy too. (Binod)

Participants reported that their training had consisted of how to operate the devices they were given, and how to relate the contents to their lesson plans:

That was basic computer skills of how to open, shut down, copy texts, download, and other essential things. Still, at least we know how to open the devices, teach lessons with them and shut down the devices. (Chetan)

The training focused on the use of digital device, but we equally learned to prepare plans by using both this device and the textbook. (Bikash) 


\section{Infrastructures available}

Annapurna, Buddha and Chadani Schools had their computer labs in use. Annapurna School had both XO laptops and desktop computers, but Buddha and Chadani Schools had only XO laptops in their lab. All of them had a local server and routers to run an e-library in the school's premises. Annapurna and Chadani Schools had electricity to charge the devices and a backup battery to run the server. However, Buddha School had installed a 3.0 KW solar panel, as there was no hydropower extension in the area. Dhaulagiri School lost its computer lab in the April 2015 earthquake, and Ekata School kept the lab unused. The teachers at Ekata School were unwilling to discuss why the school had closed the lab.

The XO laptops contained course materials for Science, Mathematics, Nepali and English. They connected with a local server installed in the school and could open an elibrary. The devices had several other applications such as wiki, paathmala, a discussion board, colouring activities, and some games. It was found that the discussion board had been tried out by several teachers but not used in teaching. For example,

We can chat one to another on this device. Binod and I tried that before. But we never involved children in that space. (Bikash)

We use them to search the books. I have not tried to open Google sites or Facebook on those devices. It's a good teaching material. (Chitra)

\section{Barriers experienced}

Annapurna School lacked wire internet service although the village had electricity and a cellular mobile phone service. Buddha School may not get wired internet access for another decade. The people in the village had 2G mobile data access, but it was not reliable. The villages where Chadani, Dhaulagiri and Ekata schools are located had internet facility but the schools were not connected to the internet. Participants in these schools reported that there 
was little knowledge of ICT in the community, and schools' financial problems prevented getting internet facility in their school.

We talked to head teacher, but he showed us the problem of the bill. (Deepa)

There’s no internet. But internet is essential today for children. (Elisha)

While mobile data can be an alternative to internet access in some of the less mountainous remote villages, it is too expensive for the common people and for schools. Some of the participants stated that they used mobile data to browse information on Google and to open Facebook. For example:

Sometimes I open Facebook and search information from the Ministry of Education, Teacher Commission vacancies. My mobile is very small, so it's hard to view. It would be easier if I had a bigger screen to open things like Sajilo English bolne (easy Englishspeaking app). (Anuj)

That is up to the school. There may be a possibility in this area because there is $3 \mathrm{G}$ data service. (Binod)

The brevity of training was found to impact in a number of ways. Some participants did not feel comfortable in integrating the digital resources with the government textbook, and others complained that they had not learned enough to navigate problems in operating the devices.

Textbooks have different contents than devices. I teach them separately. It is hard. (Asha).

There was device hanging problem. They didn't say anything about that. There is chat function between the devices. We couldn't learn that well. Sometimes we couldn't find technical solutions of functions. (Binod)

\section{Use made of digital devices in teaching}

As explained above, only three of the schools studied were making active use of the digital devices at the time of the study. In these schools, teachers tended to follow the 
textbook in the classroom and follow it up with more self-paced work on the digital devices in the computer lab.

What we do is we prepare our plan integrating textbook contents and e-paath contents. We make that plan so that the children can learn both contents well. (Chetan)

In the textbook, we find just limited examples, but there are many practice-oriented materials on these devices. The teachers give activities to the students and just support them. (Ananda)

Just giving a lecture does not make good teaching. In the lab we go through problems with groups of students, ask them individually to participate in interaction or discussion or tell us their problems. (Chiran)

They can try the same problem several times until they solve the problem, which is not possible in the classroom. In the class, I give one problem on the whiteboard that they do. There are several exercises and many practical activities on this device. (Anuj)

\section{Changes to teaching approach}

Nepali classrooms, especially those in rural schools, have tended to be teacher-centred with teachers lecturing or reading from the textbook. Participants enthusiatically talked about how their teaching had changed in the lab environment to being more student-centred.

I used to use chalk and talk and shout a lot while teaching Maths. Students were afraid of asking questions. Since we got these devices, I do not have to shout, and I just go to every student because they are with their individual devices. They openly share their problems now. (Ananda)

They can try the same problem several times until they solve the problem, which is not possible in the classroom. In the class, I give one problem on the whiteboard that they do. There are several exercises and many practical activities on this device. (Anuj)

Children can do exercises on their own. If they have incorrect answers, the voice speaks, and they can revise it until they correct. There is no chance of cheating. They can work themselves; the teacher just facilitates. (Chiran) 


\section{Changes in relationship with students}

Participants also commented on the way their relationship with children changed, from a role of authority that elicited compliance and even fear, to one of trust and support.

\footnotetext{
We behave like friends. They might have had the feeling 'Am I weak in the study or less than someone?' That is a kind of hesitation in them. So, their involvement with their classmates is really supporting them to learn. (Chitra)
}

Children ask me without hesitation when they don’t understand contents. (Anuj)

In brief summary, it was found that both digital infrastructures and training in their use have been provided in all five schools by an NGO and not by the government. It was also found that two schools had stopped using their devices, one because of natural disaster and the other for unexplained reasons, three schools were actively using them to complement the textbook resource and to allow students to work more independently and enjoyable. The participants in the three schools utilising the devises claimed that their relationships with students were freer and students were more motivated to learn at their own pace. Participants across all five schools noted problems with the short length and scope of the training, the lack of internet access and the limitations of schools’ financial ability to support digital maintenance and improvement. The following discussion will examine these findings in terms of policy implementation using Weaver-Hightower's (2008) policy ecology model.

\section{Discussion: an ecological view of implementation of Nepal's policy for ICT in education}

It was found that two separate systems operate in implementing ICT in education in Nepal. At the practical operational level, these two separately evolving systems can be regarded as parts of one ecosystem that, temporarily at least, sustains policy and classroom use. 
The Ministry of Education develops educational policy, such as the ICT in Education Master Plan, 2013. The Curriculum Development Center develops national curriculum and the Center for Education and Human Resource Development prepares teacher development programmes and provides general professional development training for in-service teachers with the coordination of District Education Offices in Resource Centers. Because the government does not provide ICT training or fund the provision of ICT resources, these bodies are not enough. However, because the government invites the collaboration of NGOs, the NGOs become active, though perhaps temporary, agents of implementing the policy. Within this loosely framed collaboration, NGOs are allowed to develop their own programmes, more or less in accordance with government policy. Teachers and schools need ICT infrastructure in their schools and information and technology (IT) experts to teach how to operate them. NGOs bring their own networks of international organisations that fund the content development, provide hands-on teacher training, install computer labs in schools and provide continuous technical support. Here we examine the extent to which the two systems form a co-evolved ecology that is not only currently surviving but may also perhaps generate a more sustainable evolution of ICT in education within Nepal's environment.

Weaver-Hightower (2008) defines key elements in policy ecology: actors, relationships, environments and structures, and processes. In the category of actors fall all the individuals and groups with varying power and roles in the ecology. In the Nepali context these are the policymakers, NGOs, educators, learners, and, latently, parents and members of the wider community. These actors and the behavioural interactions between them are summarised in Figure 1. 


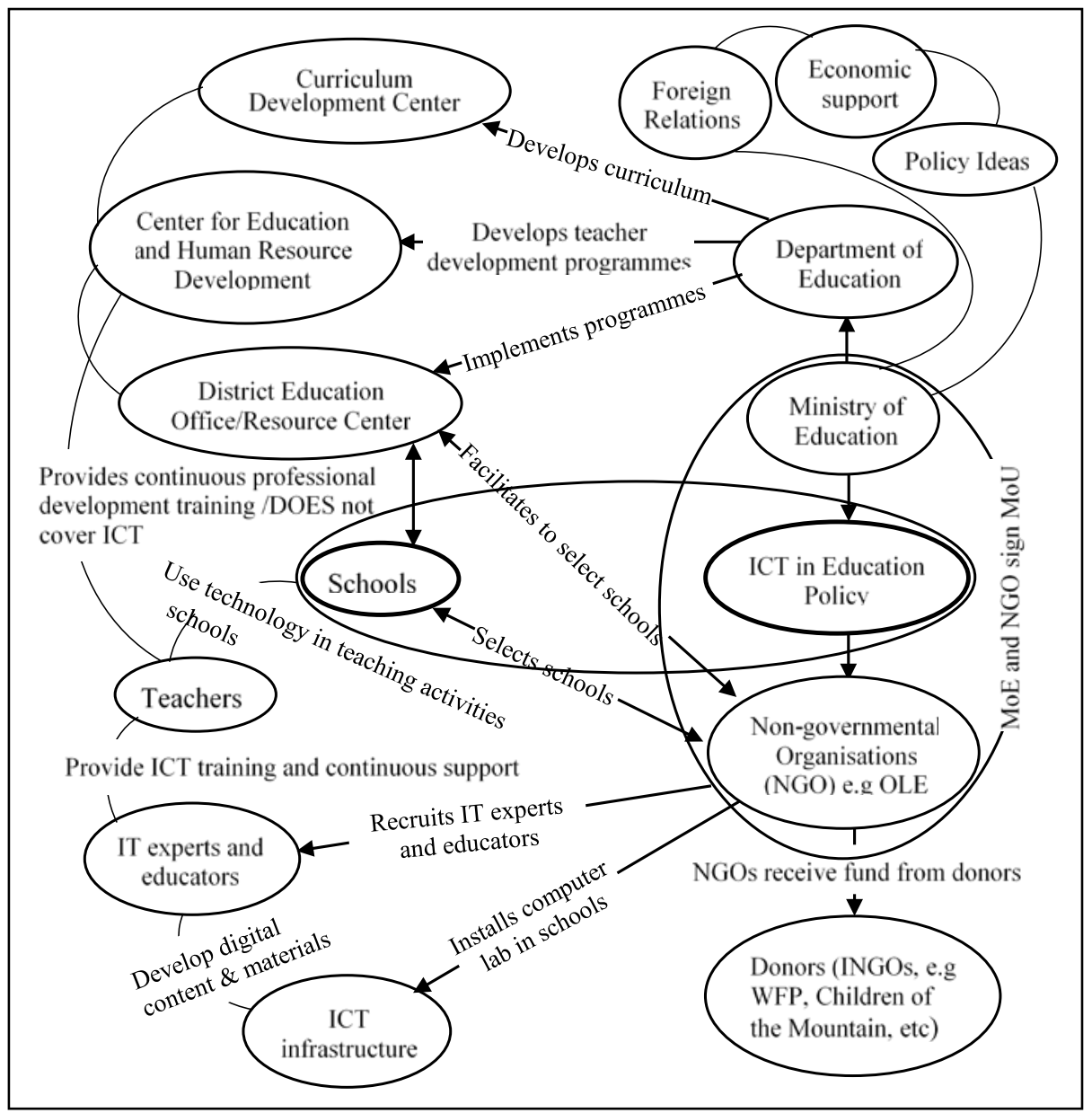

Figure 1: Ecological model of ICT in Education policy implementation

These actors may exist in relationships that are competitive, cooperative, predatory or symbiotic. The research study found that government and NGO teacher training programmes were conducted separately and independently. Teachers received generalist government training and ICT training from the NGO at different times. A cooperative relationship is indicated by the ways the NGO and rural school teachers work together to integrate digital technology in teaching and learning. A symbiotic relationship, one where actors work independently for mutual gain, can be seen in the way the NGO and government agencies each independently provide various fields of training and develop teaching resources. Government centres focused on transformation of traditional pedagogy to child-centred teaching strategies, NGOs on acquisition of ICT knowledge and skills; they did not actively cooperate in developing teacher training programmes. Because NGOs and the government 
agencies co-exist interdependently for their mutual gain, the relationship could be considered as symbiotic rather than actually cooperative. At the time of the research, there was no evidence or competition or predation. It appears that the government has created an environment where the NGO in this study, like others, has found niches where it has evolved its own systems and its own relationship with schools and teachers, in co-existence with government agencies. Together the two systems are co-evolving an environment and process that enables them both to survive and evolve their own policies and plans.

In discussing environments and structures, Weaver- Hightower highlights extent conditions, boundaries, pressures, niches, inputs, agency and adaptive decentralisation. Among the extant conditions in this case the resources of a developing country, the economic divide between urban and rural areas, the poor economic conditions and difficult geographical locations of rural communities, the country’s continuous vulnerability to earthquake damage, and the national policy and curriculum. These factors contribute to the creation of an overall environment in which it is easier to develop policy statements and accompanying curriculum than to implement and resource it. Within this overall environment, there is a boundary within which the actors operate: in this case the rural primary schools of Nepal. An agreement between the Ministry of Education and the NGO of this study provided a jurisdictional boundary for NGO to create own ecological environment where the various actors interact and develop active relationships to survive in the existing environment. Further extant conditions in the environment, such as lack of government investment in ICT infrastructure and in the development of teacher's ICT knowledge and skills, as well as the poverty of rural communities, created pressures on schools and teachers in terms of need for resources, information and skills, so evolving a niche for the NGO to operate. Although most of the teacher participants in the research study talked only about their experiences of training with ICT and using ICT in their own teaching, some noted the 
shadow presence of large international development projects and global funders. For example, one teacher observed: “Actually this has connection with the World Food Programme. They visited this school. Then we got this technology from the NGO.”

A further pressure that forces a change in the environment is a global movement towards digitalisation together with the financial conditions of teachers and their communities that mean they could not afford expensive digital devices. The entry of the NGO into the environment relieves some of the pressure and creates an opportunity for new developments in classroom practice. Many of the teachers interviewed for the study expressed their appreciation that the use of digital devices in their teaching activities changed their traditional chalk-talk teaching strategy to child-centred pedagogy. However, some new pressures were also created: a few teachers complained that since the introduction of digital devices they now needed to teach the same lesson twice - once in regular class with official textbooks and again in the lab with the slightly different content on the digital devices. Both reactions suggest that the ecology is still in a process of evolution.

Successful functioning of this evolving policy ecology relies on a number of crucial inputs such as foreign aid in order to make resources available for the actors. However, the continuance of foreign aid is dependent on many factors that are outside this particular policy ecology, such as global politics and movements in a global market-driven economy. There are questions to be asked about how an NGO can secure long-term foreign aid and about whether alternative internal resources could be developed to continue funding for e-learning programmes in schools. The niches and roles that have developed operate dynamically at the time of this study, but it is yet to be seen whether they will continue to develop and whether the ecology that involves those niches and roles will continue to emerge or will lead to entropy. This ecology is not an independent entity, it is dependent on other powerful systems that are in various states of change nationally and globally. 
This study found that NGO developed its own plan to select rural schools, with some explicit support from government offices and donor organisations. However, the various donor organisations were found to exert agency that is power to influence and potentially change the ecology. For example, the NGO in this study supported over 43 schools in a mountainous district with ICT infrastructure, teacher training and other essential resources because of the influence of World Food Programme which had supported all the schools of the district. Moreover, the current decentralised school management system, a system that requires local communities to take responsibility of managing schools, allows schools to be agentic in exploring the availability of resources, such as gaining computer lab support from the NGO. Ecologies evolve rather than being controlled by a central power, and in the rural regions of Nepal the lack of centralised government control over the implementation of ICT in education allows for a process of decentralised adaptation in which organisations such as this NGO and individuals such as its director can become agentic in bringing in other actors and donors. In a Swedish study that also drew on the metaphor of ecology, Folke, Hahn, Olsson and Norberg (2005) also found that the process of implementing ICT in education relied on the collaboration of a diverse set of actors such as schools, municipalities, District Education Office, regional and national organisations, Department of Education, Curriculum Development Centre, teacher development center, teachers, teacher trainers, content developers and international organisations.

\section{An ecology that is still changing}

As Weaver-Hightower (2008) pointed out, social ecologies continuously change as the pressures and influences on actors develop and as resulting relationships shift. He describes the changes in terms of a range of possible processes: emergence, entropy, adaptation, conversion, succession, conservation, anticipation. The advent of the NGO into the arena of ICT development in rural Nepali primary schools can itself be seen a shift in an 
existing ecology and as a catalyst for what Weaver- Hightower calls conversion or dramatic change to the structures and dynamics of the ecology. Over time the ecology has adapted to the input of NGO and a kind of equilibrium has developed, at least temporarily, which integrates policy development, resource supply and classroom adaption by teachers. However, the process of classroom adaption by teachers is not a uniform or static process. The supply of computer labs with sets of individual devices (XO-laptops, specifically designed and programmed for teaching and learning), of digital libraries of curriculum contents and of training courses in their use has created new environments in schools, bringing changes in teachers' teaching practices and in their relationship with students. New possibilities are opening up.

This study found that the teachers interviewed were learning, in various ways, to use digital technology in their instructional activities, so accommodating to the changed environment and in turn again beginning to change the environment. The adaptation of new technology in classroom teaching gradually shifted the classroom teaching and learning environment. The use of digital technology in the classroom processes of teaching and learning was found to be gradually diminishing teachers' use of a chalk-and-talk teaching strategy and creating an environment where children were given more freedom in their learning by being able to move independently on their individual devices. Not only were teachers gradually changing their practice, but the students also were forming new and different expectations of what was involved in going to school and of how they could learn.

However, it can be argued that the shift in teaching practices is only at an initial change of what could be possible with the use of technology and the availability of individual devices. It might take considerably more time to shift from traditional pedagogy to modern teaching and learning strategies in the rural regions due to factors outside the control of schools. These include lack of web access in most of rural areas, low level of digital literacy, 
low income of teachers, substance levels of economy in rural communities and consequent inability to pay for expensive digital technology, as well a lack of government investment in ICT infrastructure in village communities as well as in schools. It might also be argued that the shift in teaching practices might break down if there is no extension of the currently provided ICT training for teachers and if resources are not augmented. The study found that there was already a backwards shift in practice in the case of two schools studied: one had lost its computer labs in the 2015 earthquake and had not been able to have them replaced; the other had closed down its existing lab for reasons they teachers were unwilling to discuss.

The adoption of digital technology in classroom teaching and learning activities has, to some extent, disrupted the traditional culture of using printed textbooks as the teaching and learning resource for teachers and students, and created a new way of teaching and learning in the classroom. However, there is a potential and predictable risk in maintaining the ecology as it has evolved with the entrance of NGO into the process of policy implementation. The ecology now relies on international donor organisations which have only committed to provide funding for a certain time. The processes for supplying infrastructures to allow the implementation of policy and the shifts in teaching could collapse if the donor organisations stop their support to the NGO or if the NGO adopts new strategic objectives. The critiques, cited in the literature review, of NGO involvement in developing countries argue that governments cannot rely on continuing partnerships. It is, therefore, important for the Government of Nepal to not only utilise the support of the NGO in its policy implementation but also to analyse the potential risk of that support being discontinued or diminished. It needs to anticipate the risk and take timely steps to either consolidate the relationship or develop other means of funding the use of digital technology in education. 


\section{Conclusion}

The current level of success in implementing the ICT in education policy in rural schools in Nepal has been achieved by the work of two unconnected systems, the Department of Education and its operational bodies, and the NGO and its agents, to variously provide for rural schools. None of the actors in the system, agency or individual, is responsible for the whole programme. Rather the actors in the ecology, as a whole, have developed roles and relationships according to niches that were available and needs and opportunities that they perceived. The interrelationship that evolved among them has sustained the survival of the policy the actors are currently involved in. To an extent, the two largely symbiotic systems have resulted in successful implementation of ICT in education in the resource-poor rural context of Nepal.

Currently, there is no strategic document that states criteria for involving NGOs and other development organisations in the implementation of educational policy. We argue that a symbiotic relationship has evolved organically and, further, that the resulting co-development is, at least currently, somewhat effective in implementing the policy for the use of ICT in education. We have thus suggested that a model of policy implementation ecology can help explicate the current roles of NGOs and government in implementation of ICT in education and illustrated how the relationship functions in terms of an ecological model.

We argue not only that the model is useful in explaining what is already occurring, but also that model helps to identify dangers that may occur. An ecology is the description of a living and changing collection of organisms and their relationship to each other and their environment. The model carries an implicit expectation that the relationships will continue to evolve and that some actors will gain power while others lose it and that new actors may develop to occupy new niches. It also carries an implicit expectation that the environment itself may change, either in a direction of growth, such as the emergence of new teaching 
strategies or of destruction, such as the loss of resources in the earthquakes. The model indicates the importance of looking at relationships and at what sustains or threatens them, as well as looking at new direction that is emerging and at what is likely to sustain or threaten them.

In the situation where the government cannot afford to invest in the infrastructures a government strategy, deliberate or fortuitous, of enabling others to implement ICT in its schools seems to be both necessary and useful. In another national context, Basye (2014) reported that because small districts and communities have limited budget to purchase expensive technology for schools the US government has had to provide special funding and strategic partnerships. Thapa (2011) has reported that in Nepal the local people in rural contexts cannot afford expensive digital devices, and Rana (2018) reported the government's inability to provide infrastructures. The NGO in this study has generated infrastructures, in a partnership which is in accordance with the suggestion by the World Bank (2018) that the use of technology in education in the developing world can be facilitated by strategic partnerships with agencies in developed countries. The use of policy implementation ecology as a lens to examine the resulting complex system and the partnerships within it allows us to understand and explain how policy initiatives have been relatively successful in the context and to critically examine the extent to which they are likely to be sustainable.

Discussion of an ecology-based model of examining policy implementation suggests the need for developing countries taking initiatives of integrating ICT into education (or other initiatives that follow the practice of developed countries) to carefully analyse their contexts, and to consider how various external agencies could take a role, what relationships would be desirable as well as possible, what directions are likely to emerge and what changes may be created by shifts in external factors such as global politics and funding. Ecologies develop because of environments and the needs and actions of actors within the environment. 
Developing countries probably need external partnerships. In order to create sustainable development, they need to analyse how the partnerships will operate. We argue that an ecology model is a useful lens for such analysis.

We also argue that the government of Nepal needs to exercise what WeaverHightower (2008) calls anticipation, that it needs to predict the future ICT needs of schools (after considering possible reduction of funding by NGOs and possible destruction in earthquakes) and develop strategic and practical plans that will allow it to act to meet those needs. It may not be able to do so alone. Its policy implementation ecology may always need partners, but it does need to understand the working of the ecology.

In the preceding discussion the ecological model, as adapted from Weaver-Hightower (2008), provided a lens for a critical analysis that allowed for consideration of the multiple actors by whom policy is operationalised, rather than restricting focus to actions, and lack of actions, of government. The concept of evolving ecology has facilitated positive consideration of the role played by external agencies such as the NGO in this study. This has been particularly useful for exploring the workings of policy in a developing country such as Nepal, where government is challenged by compliance with international expectations as well as constrained in financial resources. By the very factors that allow it to be seen as developing, a developing country is both in catch-up mode and poorly resourced to succeed in catching up. Partnerships of some kind are needed.

A potential danger in such a model is that it could invite uncritical acceptance of the status quo, thus excusing government from developing contextually specific and strategic implementation plans, and unquestioningly validating the intervention of foreign interests. In our use of the model we have paid particular attention to the evolving nature of the ecology and its interdependence with wider ecological systems, so highlighting the possibly fragile nature of its current operational effectiveness and the risks to the people of Nepal if the 
external actor, the NGO, is caused to withdraw or change its role. Possible further development of the model could involve strategies to identify ecological instabilities and risk. However, most importantly, we would argue that a model of this kind is most useful as an analytical tool that provokes different ways of seeing a situation, rather than as a construct that defines the situation. Seeing policy in terms of a fluid dynamic ecology does not prevent, and we would argue that it should not replace, critical examination of the usefulness, ethicality and practicality of the policy itself or of the actors who contribute to its implementation.

\section{References}

Ashraf, M., Hanisch, J., \& Swatman, P. (2009). ICT intervention in the 'Chandanbari’Village of Bangladesh: Results from a field study. Information Systems Frontiers, 11(2), 155166.

Asian Development Bank. (2005). Overview of Civil Society: Nepal. https://www.adb.org/publications/overview-civil-society-nepal

Baker, S., \& Eckerberg, K. (2013). A policy analysis perspective on ecological restoration. Ecology and Society, 18(2). doi: 10.5751/ES-05476-180217

Ball, S. J. (1998). Big Policies/Small World: An introduction to international perspectives in education policy. Comparative Education, 34(2), 119-130. doi: 10.1080/03050069828225

Banks, N., Hulme, D., \& Edwards, M. (2015). NGOs, States, and Donors Revisited: Still Too Close for Comfort? World Development, 66, 707-718. doi: http://dx.doi.org/10.1016/j.worlddev.2014.09.028

Basye, D. (2014). Reaching Rural Schools: Technology Makes Learning Possible No Matter the Zip Code. Retrieved from https://www.clarityinnovations.com/blog/dbasye/reaching-rural-schools-technology-makes-learningpossible-no-matter-zip-code

Beyer, C. (2007). Non-Governmental Organizations as Motors of Change. Government and opposition, 42(4), 513-535.

Bhandari, A., \& Onta, P. (2017 February 24; retrieved 2017 September 9). Revisiting the NGO numbers debate, The Kathmandu Post. Retrieved from http://kathmandupost.ekantipur.com/news/2017-02-24/revisiting-the-ngo-numbersdebate.html 
Bhandari, M. (2014). Civil Society and Non-Governmental Organizations (NGOs) Movements in Nepal in terms of Social Transformation. The Pacific Journal of Science and Technology, 15(1), 177-189.

Bhatta, S. D. (2008). Tackling the problems of quality and disparity in Nepal's school education: The OLPC Model. Studies in Nepali History and Society, 11(1), 00-00.

Bronfenbrenner, U. (1979). The ecology of human development: experiments by nature and design. Cambridge, Mass: Harvard University Press.

Carney, S., \& Bista, M. B. (2009). Community Schooling in Nepal: A Genealogy of Education Reform since 1990. Comparative Education Review, 53(2), 189-211. doi: $10.1086 / 597394$

Carney, S., \& Rappleye, J. (2011). Education reform in Nepal: from modernity to conflict. Globalisation, Societies and Education, 9(1), 1-9. doi:

10.1080/14767724.2010.513274

Dawadi, B. R., \& Shakya, S. (2016). ICT Implementation and Infrastructure Deployment Approach for Rural Nepal. In P. Meesad, S. Boonkrong \& H. Unger (Eds.), Recent Advances in Information and Communication Technology 2016: Proceedings of the 12th International Conference on Computing and Information Technology (IC2IT) (pp. 319-331). Cham: Springer International Publishing.

Dixit, U. (2009). The use of ICT in teacher training: Nepal's experience. Paper presented at the 13th UNESCO-APEID International Conference on Education, Hangzhou, China.

Firestone, W. A. (1989). Educational Policy as an Ecology of Games. Educational Researcher, 18(7), 18-24. doi: 10.3102/0013189X018007018

Folke, C., Hahn, T., Olsson, P., \& Norberg, J. (2005). Adaptive governance of socialecological systems. Annual Review of Environment and Resources, 30(1), 441-473. doi: 10.1146/annurev.energy.30.050504.144511

Gurung, A., Gurung, O. P., Karki, R., \& Bista, R. (2011). Impact of Non-Governmental Organizations in the Rural Community Development: A Case Study from the TransHimalayan Region of Nepal. International Journal of Applied Sociology, 1(1), 1-7. doi: 10.5923/j.ijas.20110101.01

Internet World Stats. (2017). Internet Usage in Asia. Retrieved from http://www.internetworldstats.com/stats3.htm

Islam, K. (2010). People Driven Innovation - How to create the Demand for ICT Solutions in Underserved Areas. In A. Picot \& J. Lorenz (Eds.), ICT for the Next Five Billion People: Information and Communication for Sustainable Development (pp. 15-23). Berlin, Heidelberg: Springer Berlin Heidelberg.

Ismail, F. (2017). Polar opposites? NGOs, left parties and the fight for social change in Nepal. Critical Sociology. doi: 10.1177/0896920517715765

Ivins, T. Z. (2011). Localization of open educational resources (OER) in Nepal: Strategies of Himalayan knowledge-workers: Brigham Young University. 
Khan, M., Hossain, S., Hasan, M., \& Clement, C. K. (2012). Barriers to the Introduction of ICT into Education in Developing Countries: The Example of Bangladesh. Online Submission, 5(2), 61-80.

Lister, S. (2003). NGO Legitimacy. Critique of Anthropology, 23(2), 175-192. doi: 10.1177/0308275X03023002004

MoE. (2009). School Sector Reform Plan 2009-2015. Kathmandu: Ministry of Education, Government of Nepal.

MoE. (2016). School Sector Development Plan, 2016-2023. Ministry of Education, Government of Nepal.

MoES. (2005). National Curriculum Framework for School Education (Pre-primary - 12) in Nepal. Sanothimi, Bhaktapur: Ministry of Education and Sports, Government of Nepal.

MoES. (2007). National Curriculum Framework for School Education in Nepal. Sanothimi, Bhaktapur: Curriculum Development Centre, Ministry of Education and Sports.

MoIC. (2015). National Information and Communication Technology Policy, 2015. Ministry of Information and Communication, Nepal.

MyRepublica. (2017, March 15; retrieved 2017 August 18). OLE Nepal helping schools connect through e-library, My Republica. Retrieved from http://www.myrepublica.com/news/16511/

News24Nepal. (2017 September 1; retrieved 2017 September 11). Fifteen million use internet, News24 Channel. Retrieved from http://www.news24nepal.tv/2017/09/01/175553

Pangeni, S. K. (2016). Open and distance learning: Cultural practices in nepal. European Journal of Open, Distance and E-learning, 19(2), 32-45. doi: 10.1515/eurodl-20160006

Rana, K. (2018). ICT in rural primary schools in Nepal: context and teachers' experiences. (Thesis). University of Canterbury, New Zealand. Retrieved from https://ir.canterbury.ac.nz/handle/10092/457

Rana, K., Greenwood, J., Fox-Turnbull, W., \& Wise, S. (2018). A shift from traditional pedagogy in Nepali Rural Primary Schools? Rural teachers' capacity to reflect ICT policy in their practice. International Journal of Education and Development using ICT, 14(3). doi: http://ijedict.dec.uwi.edu/viewarticle.php?id=2521

Rappleye, J. (2011). Catalysing educational development or institutionalising external influence? Donors, civil society and educational policy formation in Nepal. Globalisation, Societies and Education, 9(1), 27-49. doi: 10.1080/14767724.2010.513517

Regmi, K. D. (2017). World Bank in Nepal's education: three decades of neoliberal reform. Globalisation, Societies and Education, 15(2), 188-201. doi: 
Rennie, F., \& Mason, R. (2007). The development of distributed learning techniques in Bhutan and Nepal. The International Review of Research in Open and Distributed Learning, 8(1).

Rosenbaum, N. (1980). Statutory structure and policy implementation: The case of wetlands regulation. Policy studies journal, 8(4), 575-596. doi: 10.1111/j.15410072.1980.tb01268.x

Sabatier, P., \& Mazmanian, D. (1980). The Implementation of Public Policy: A Framework of Analysis. The Policy Studies Journal, 8(4), 538-560. doi: 10.1111/j.15410072.1980.tb01266.x

Scientology. (2017 August 18). Nepalese educators embrace study technology. Retrieved from http://www.scientology.org/how-we-help/applied-scholastics/communityactions/nepal.html

Sharma, R. D. (2017 May 24; retrieved 2019 May 1). Nepal braces for deceleration in per capita income growth, The Kathmandu Post. Retrieved from http://kathmandupost.ekantipur.com/news/2017-05-24/nepal-braces-for-decelerationin-per-capita-income-growth.html

Shields, R. (2011). ICT or I see tea? Modernity, technology and education in Nepal. Globalisation, Societies and Education, 9(1), 85-97. doi: 10.1080/14767724.2010.513536

Smith, E. (2009). Improving Teacher Quality: A Role for Accountability Policies? In A. Selkirk \& M. Tichenor (Eds.), Teacher Education: Policy, Practice and Research (pp. 123-135). New York: Nova Science Publishers.

Smith, J. A., Larkin, M., \& Flowers, P. (2009). Interpretative phenomenological analysis: theory, method and research. London \& Los Angeles;: SAGE.

Stake, R. E. (2006). Multiple Case Study Analysis. New York: The Guilford Press.

Tanaka, M. (2011). The Changing Roles of NGOs in Nepal: Promoting Emerging RightsHolder Organizations for Inclusive Aid. Voluntas: International Journal of Voluntary and Nonprofit Organizations, 22(3), 494-517.

Terje, T. (1998). Angels of Mercy or Development Diplomats? NGOs and Foreign Aid. James Currey, Oxford: Africa World Press, Trenton.

Thapa, D. (2011). The role of ICT actors and networks in development: The case study of a wireless project in Nepal. The Electronic Journal of Information Systems in Developing Countries, 49(1), 1-16. doi: doi:10.1002/j.1681-4835.2011.tb00345.x

Thapa, D., \& Saebo, O. (2011). Demystifying the Possibilities of ICT4D in the Mountain Regions of Nepal. Paper presented at the System Sciences (HICSS), 2011 44th Hawaii International Conference on.

Wallenius, T. J. (2017). Challenging gender roles through STEM education in Nepal. (Thesis: Master of Arts in Education). California State University, Long Beach. 
Weaver-Hightower, M. B. (2008). An Ecology Metaphor for Educational Policy Analysis: A Call to Complexity. Educational Researcher, 37(3), 153-167. doi: 10.3102/0013189X08318050

World Bank. (2015). ICT and Education - Key Issues. Retrieved from http://web.worldbank.org/WBSITE/EXTERNAL/TOPICS/EXTEDUCATION/0,,cont entMDK:20533883 menuPK:617610 pagePK:148956 piPK:216618 theSitePK:282 386 isCURL:Y,00.html

World Bank. (2018). Education and Technology. Retrieved from http://www.worldbank.org/en/topic/edutech

Yawson, R. M. (2009). The ecological system of innovation: A new architectural framework for a functional evidence-based platform for science and innovation policy. The Future of Innovation Proceedings of the XXIV ISPIM 2009 Conference, Vienna, Austria, June 21-24, 2009.

Zhao, Y., \& Frank, K. A. (2003). Factors affecting technology uses in schools: An ecological perspective. American educational research journal, 40(4), 807-840. 